\title{
P75. Genetic engineering of T cells for increased homing to the tumor site
}

\author{
M Idorn", GH Andersen, HL Larsen, JH van den Berg, Ö Met, P thor Straten \\ From 1st Immunotherapy of Cancer Conference (ITOC1) \\ Munich, Germany. 12-14 March 2014
}

Adoptive cell transfer (ACT) using in vitro expanded $\mathrm{T}$ cells from biopsy material represents a highly promising treatment of disseminated cancer. ACT in its present form is rather crude and improvements seem within reach. Recruitment of transferred lymphocytes to the tumor site is a crucial step in ACT efficacy; however, quite few $\mathrm{T}$ cells actually reach the tumor site upon administration. In the present pre-clinical study we have genetically engineered $T$ cells aiming at increasing the homing of $\mathrm{T}$ cells by matching expression of chemokine receptors on $\mathrm{T}$ cells to chemokines secreted by the tumor, thus improving anti-tumor efficacy of ACT. By PCR analysis we found that several malignant melanoma (MM) cell lines showed expression of cytokines CXCL8/ IL-8, CXCL12/SDF-1 and CCL2, which was confirmed by ELISA analysis of MM conditioned medium. Taking advantage of mRNA electroporation we successfully transfected $\mathrm{T}$ cells with mRNA encoding the chemokine receptors CXCR2 and chimeric receptor CXCR4-R2 on the cell surface, the latter expressing the intracellular region of CXCR2 allowing expression in T cells. Work is in progress, but so far chemokine receptor CXCR2 and chimeric receptor CXCR4-R2 transfected T cells are capable of migrating towards their ligands, CXCL8 and CXCL12 respectively, in in vitro transwell migration assays. In vitro studies on the transfection and function of the CXCR4 and CCR2-R2 chimeric receptors as well as in vivo migration studies have been initiated, and data will be presented at the meeting.

Published: 12 March 2014

Center for Cancer Immunterapi, CCIT, Herlev Universitets Hospital, Herlev Ringvej 75, 65Q9, 2730 Herlev, Denmark
doi:10.1186/2051-1426-2-S2-P49
Cite this article as: Idorn et al:: P75. Genetic engineering of T cells for increased homing to the tumor site. Journal for ImmunoTherapy of Cancer 2014 2(Suppl 2):P49.

Submit your next manuscript to BioMed Central and take full advantage of:

- Convenient online submission

- Thorough peer review

- No space constraints or color figure charges

- Immediate publication on acceptance

- Inclusion in PubMed, CAS, Scopus and Google Scholar

- Research which is freely available for redistribution 